\title{
Clinical characteristics and severity of COVID-19 among Mexican adults
}

\author{
Miguel A. Pérez-Sastré, ${ }^{1}$ Jesús Valdés² and Luis Ortiz-Hernández ${ }^{3 *}$ \\ ${ }^{1}$ Master's Degree and Doctorate Program in Medical, Dental and Health Sciences, Universidad Nacional Autónoma de México, ${ }^{2} B i o c h e m i s t r y$ \\ Department, Center for Research and Advanced Studies, Instituto Politécnico Nacional; ${ }^{3}$ Health Care Department, Universidad Autónoma \\ Metropolitana, Xochimilco Unit. Mexico City, Mexico
}

\begin{abstract}
Introduction: Obesity, diabetes, hypertension and age have been pointed at as factors that influence on the progression of COVID-19; however, evidence for other conditions is inconclusive. Objective: To identify which clinical characteristics are related to COVID-19 severity and to determine whether age acts a modifier of the relationship between cardio-metabolic comorbidities (CMC) and COVID-19 progression. Method: Data on $\geq 20$-year-old confirmed cases $(n=159,017)$ were analyzed. Hospitalization, development of pneumonia, intubation requirement, intensive care unit admission and death were the dependent variables in Poisson regression models estimation, whereas the interaction between age and different CMCs were the independent variables. Results: Having CMCs, as well as other comorbidities, was directly related to COVID-19 progression, whereas chronic obstructive pulmonary disease was only related to an increase in the risk of dying. The risk for COVID-19 severity was lower as age was more advanced. Asthma and smoking were not risk factors for the progression of COVID-19. Conclusion: In the Mexican population, the risk of COVID-19 progression associated with comorbidities was higher in young adults.
\end{abstract}

KEY WORDS: Obesity. Hypertension. Diabetes. Asthma. Smoking. Coronavirus infection. Age. Young adult.

\section{Características clínicas y gravedad de COVID-19 en adultos mexicanos}

\section{Resumen}

Introducción: Se ha señalado que factores como obesidad, diabetes, hipertensión y edad influyen en la progresión de COVID-19; sin embargo, la evidencia para otras condiciones no es concluyente. Objetivo: Identificar qué antecedentes clínicos están relacionados con la gravedad de COVID-19 y si la edad funge como un modificador de efecto de la relación entre comorbilidades cardiometabólicas (CCM) y progresión de COVID-19. Método: Se analizaron los datos de casos confirmados $\geq 20$ años ( $n=155$ 017). La hospitalización, el desarrollo de neumonía, el requerimiento de intubación, el ingreso a la unidad de cuidados intensivos y la muerte constituyeron las variables dependientes en la estimación de modelos de regresión de Poisson y la interacción entre edad y CCM, las independientes. Resultados: Tener CCM, así como otras comorbilidades, se relacionó directamente con la progresión de COVID-19. El riesgo de gravedad de COVID-19 asociado a las CCM fue menor conforme la edad era mayor. El asma y el tabaquismo no fueron factores de riesgo para la progresión de COVID-19. Conclusión: En la población mexicana, el riesgo de progresión de COVID-19 asociada a comorbilidades fue mayor en los adultos jóvenes.

PALABRAS CLAVE: Obesidad. Hipertensión. Diabetes. Asma. Tabaquismo. Infección por coronavirus. Edad. Adulto joven. 


\section{Introduction}

In January 30, 2020, the World Health Organization declared the pandemic of the infection caused by the new coronavirus SARS-CoV-2 as a public health emergency of international relevance. By early May, there were millions of infected people and thousands of deaths. In Mexico, by June 21, there were 180,545 cases of infection and 21,825 people had died from the disease caused by this coronavirus (COVID-19). ${ }^{1}$

Research has focused on determining which demographic and medical characteristics of infected people influence on COVID-19 progression. Obesity, diabetes, hypertension and age have been pointed at as factors that influence on disease progression. ${ }^{1-3}$ However, evidence for other conditions is not conclusive; for example, the results regarding chronic kidney disease, chronic obstructive pulmonary disease (COPD), asthma ${ }^{2,4,5}$ and smoking ${ }^{6-10}$ have been inconsistent. Further investigations with less limitations than the existing ones are also required, since early studies were based on reduced samples of hospitalized subjects and no adjustments were made for confounding variables. ${ }^{2,8,9,11}$

COVID-10 behavior has been found to adopt specific characteristics according to populations' health status. It has been speculated that the degree at which COVID-19 affects the Mexican population is due to the high prevalence of obesity and other chronic conditions. In the Mexican population, obesity is more prevalent in young adults in comparison with older adults. ${ }^{12}$ In 2016, the prevalence of hypertension and diabetes in Mexican adults was $31.5 \%$ and $12.9 \%$, respectively. ${ }^{13}$ Considering the above, the purposes of this study were to identify which clinical characteristics are related to COVID-19 and to determine if age acts as an effect-modifier in the relationship between cardio-metabolic comorbidities and COVID-19 progression.

\section{Method}

In order to meet the purposes of the study, data recorded by the General Directorate of Epidemiology of the Ministry of Health, Federal Government of Mexico, on suspected and confirmed cases of SARS-CoV-2 infection were used..$^{14}$ The database concentrates information on suspected cases that have had the detection test practiced, reported to the health authority in Mexico until June 21, 2020, distinguishing between positive, negative and pending results. The database collects information on the cases reported by any medical establishment of the country. On February 28, the first case was reported in Mexico. A second source of information for the database are the cases detected through the Viral Respiratory Disease Epidemiological Surveillance System (SISVER - Sistema de Vigilancia Epidemiológica de Enfermedad Respiratoria), which started operating on April 5 of current year. ${ }^{15}$ SISVER operates through 475 respiratory disease monitoring health units (USMER - Unidades de Salud Monitoras de Enfermedades Respiratorias), distributed in all states of the country. In these units, samples are taken from $10 \%$ of viral respiratory disease outpatient cases and $100 \%$ of severe cases; the collected samples are submitted to reference laboratories to identify the presence of 14 viruses, including influenza virus and SARS-CoV-2.

The Center for Research and Advanced Studies Research Ethics Committee approved the ethical aspects of the study. The analyzed database does not contain personal data that reveal people's identity. A randomly-obtained code was used to identify them, which ensured confidentiality of the information.

In the original database, there were 479,528 records of all respiratory infection cases available. The first case of SARS-CoV-2 infection started with symptoms on January 6 , which is why records prior to that date were discarded $(n=103)$. Table 1 shows the distribution of the records with missing data; only confirmed SARS-CoV-2 infection cases were considered $(n=159,660)$. Complete data were available in $96 \%$ of cases with positive result. Subjects younger than 20 years were excluded, and the analytical sample therefore included 155,017.

As COVID-19 severity indicators, five possible outcomes were included: hospitalization, pneumonia development, intubation requirement, intensive care unit (ICU) admission and death.

Gender and age were the studied sociodemographic characteristics. Age was categorized in groups of 20 to 39,40 to 59 , and 60 years or more. A variable was also created, where age was expressed in decades (2, 20 to 29 years; 3,30 to 39 years, etc.).

SISVER records the following medical conditions: obesity, hypertension, diabetes mellitus, asthma, heart disease, immunosuppression, chronic kidney failure (CKF) and COPD. In an exploratory factor analysis (Table 2), these comorbidities were observed to be stratified in two groups: cardio-metabolic comorbidities and other comorbidities. Asthma 
Table 1. Missing data distribution according to the PCR test result to identify SARS-CoV-2 infection. Mexico, 2020

\begin{tabular}{|c|c|c|c|c|c|}
\hline \multirow[t]{3}{*}{ Missing information } & \multicolumn{4}{|c|}{ SARS-CoV-2 test result } & \multirow[t]{3}{*}{ p } \\
\hline & Total $(n=77005)$ & Positive $(n=16752)$ & Negative $(n=49033)$ & Pending $(n=11220)$ & \\
\hline & $\%$ & $\%$ & $\%$ & $\%$ & \\
\hline Ethnicity (being indigenous) & 3.11 & 2.72 & 3.32 & 3.95 & 0.000 \\
\hline Health institution sector & 0.60 & 0.61 & 0.58 & 0.68 & 0.140 \\
\hline Municipal margination & 0.02 & 0.03 & 0.02 & 0.01 & 0.003 \\
\hline Municipality size & 0.02 & 0.03 & 0.02 & 0.02 & 0.003 \\
\hline Comorbidities & 0.46 & 0.57 & 0.34 & 0.76 & 0.000 \\
\hline Asthma & 0.33 & 0.41 & 0.24 & 0.61 & 0.000 \\
\hline Cardiovascular diseases & 0.34 & 0.43 & 0.24 & 0.60 & 0.000 \\
\hline COPD & 0.33 & 0.40 & 0.24 & 0.58 & 0.000 \\
\hline Kidney failure and immunosuppression & 0.39 & 0.48 & 0.31 & 0.62 & 0.000 \\
\hline Smoking & 0.35 & 0.44 & 0.25 & 0.59 & 0.000 \\
\hline Pneumonia & 0.00 & 0.00 & 0.00 & 0.00 & 0.331 \\
\hline At least in one variable & 4.37 & 4.05 & 4.35 & 5.46 & 0.000 \\
\hline
\end{tabular}

Table 2. Exploratory factor analysis of medical conditions in the population with SARS-CoV-2 infection. México, 2020

\begin{tabular}{|l|c|c|c|}
\hline Variable & F1 & F2 & F3 \\
\hline Own value & 1.68 & 1.23 & 1.06 \\
\hline Variance (\%) & 21.0 & 15.4 & 13.3 \\
\hline Medical condition & & & \\
$\quad$ Obesity & 0.55 & -0.41 & 0.34 \\
\hline Hypertension & 0.78 & 0.01 & -0.06 \\
\hline Diabetes mellitus & 0.75 & -0.01 & -0.14 \\
Asthma & -0.14 & 0.06 & 0.86 \\
Heart disease & 0.26 & 0.35 & 0.14 \\
COPD & 0.14 & 0.35 & 0.30 \\
Immunosuppression & -0.15 & 0.72 & 0.11 \\
Chronic kidney failure & 0.31 & 0.48 & -0.22 \\
\hline COPD = chronic obstructive pulmonary disease. & &
\end{tabular}

was separately analyzed, and smoking was also considered.

The institutions where the cases were registered were classified as social security, open population and private services. The number of days elapsed between symptom onset and the provision of care at health facilities was calculated. The number of days from the onset of symptoms to the report cutoff day (June 21, 2020) was also estimated. The states were classified to identify four regions: center, north, south and west.
To measure individual socioeconomic status, the SISVER database was linked to the 2015 Municipal Marginalization Index database, ${ }^{16}$ from which information on municipalities' population size was also obtained.

The Stata program, version 15, was used to carry out the statistical analysis. Relative frequencies were obtained for categorical variables, while means were calculated for continuous variables. The chi-square test was used to identify whether there were differences between the different categories. For continuous variables, differences were searched using Student's t-test and an ANOVA, according to the number of categories of the independent variable. Prevalence of the outcomes was estimated according to the sociodemographic and medical characteristics of the cases.

Poisson regression models were estimated for each indicator of disease progression, where patient sociodemographic characteristics and medical history were the independent variables. In a first model, the main effects of all variables were estimated. In a second model, the interaction of age with cardio-metabolic comorbidities was included. Based on these models, prevalence ratios with their respective $95 \%$ confidence intervals were estimated. These models were adjusted for sociodemographic and clinical characteristics. 


\section{Results}

Half the cases recorded in the database corresponded to males, and the most common ages were between 40 and 59 years (Table 3 ). The medical condition with the highest prevalence was hypertension, followed by obesity and diabetes. The prevalence of smoking was $8 \%$. Around $30 \%$ required hospital admission, one fourth of the patients developed pneumonia, and $13 \%$ died. Nearly half the cases with a positive result were treated in an USMER. Average time to receive medical attention was 4.2 days.

The prevalence of the five COVID-19 severity indicators was higher in males, in older subjects, in those who had a higher number of cardio-metabolic comorbidities, and in those with other comorbidities whose cases were reported at an USMER and in those at the highest tertile of time elapsed to receive medical attention (Table 4). Patients with asthma had a lower prevalence of hospitalization, pneumonia, intubation and death in comparison with those without asthma. Smokers had a higher proportion of hospitalizations, pneumonia and death than non-smokers. The percentage of hospitalizations was higher in subjects at tertile 2 of time since symptom onset, while for the remaining indicators it was higher at tertile 3 .

In the models with only main effects, as age was more advanced or there were more cardio-metabolic comorbidities present, the probability of having COVID-19 severe stage indicators was observed to be higher (Table 5 and Figure 1). Having two or three comorbidities entailed having the highest prevalence ratio (PR) for all outcomes. In general, the interaction between age and number of comorbidities was significant, with a lower prevalence ratio as age was more advanced, which implies that the association between cardio-metabolic comorbidities and indicators of COVID-19 higher severity was stronger in the youngest subjects and weaker as age increased. The same results were observed for the interaction of age with other comorbidities (Table 5 and Figure 2).

After adjusting for other variables, men were at higher risk of progressing to COVID-19 more severe stages. Patients with other comorbidities were more likely to develop complications associated with the disease. As the time to receive medical attention increased, the prevalence ratio for developing pneumonia, requiring intubation or being admitted to the ICU was higher, while with regard to death it was lower. As the time from symptom onset to the cutoff date
Table 3. Characteristics of SARS-CoV-2 infection-positive Mexican adults

\begin{tabular}{|c|c|}
\hline Characteristic & $\%$ \\
\hline Men & 52.2 \\
\hline $\begin{array}{l}\text { Age (years) } \\
<20 \\
20-39 \\
40-59 \\
\geq 60\end{array}$ & $\begin{array}{c}2.9 \\
34.8 \\
41.1 \\
20.5\end{array}$ \\
\hline Obesity & 19.8 \\
\hline Hypertension & 20.5 \\
\hline Diabetes mellitus & 16.8 \\
\hline $\begin{array}{l}\text { CMC } \\
\text { None } \\
\text { One } \\
\text { Two or three }\end{array}$ & $\begin{array}{l}60.1 \\
25.6 \\
14.3\end{array}$ \\
\hline Heart diseases & 2.5 \\
\hline COPD & 1.8 \\
\hline Immunosuppression & 1.4 \\
\hline Chronic kidney failure & 2.3 \\
\hline Asthma & 2.8 \\
\hline Smoking & 8.0 \\
\hline Hospitalization & 32.5 \\
\hline Pneumonia & 25.2 \\
\hline Intubation & 2.9 \\
\hline ICU admission & 2.8 \\
\hline Death & 13.0 \\
\hline \multirow[t]{2}{*}{ Cases recorded at USMER } & 39.9 \\
\hline & Mean \\
\hline Time-to-care & 4.2 \\
\hline Time of symptom onset & 3.6 \\
\hline
\end{tabular}

$\mathrm{CMC}=$ cardio-metabolic comorbidity, $\mathrm{COPD}=$ chronic obstructive pulmonary disease, USMER (Unidades de Salud Monitoras de Enfermedades Respiratorias) = Respiratory Diseases Monitoring Units.

Time-to-care = number of days between symptom onset and care at the health establishment.

Time of symptom onset $=$ number of days between symptom onset and registry cutoff (June 21, 2020).

augmented, the prevalence of all five severity indicators became higher.

\section{Discussion}

In line with the information referred to in the literature, ${ }^{1,4,5,11,17,18}$ older age and cardio-metabolic comorbidities were associated with the development of 
Table 4. Prevalence of COVID-19 severity indicators according to sociodemographic and clinical characteristics of Mexican adults with SARS-CoV-2 infection

\begin{tabular}{|c|c|c|c|c|c|}
\hline \multirow[t]{2}{*}{ Characteristic } & Hospitalization & Pneumonia & Intubation & ICU & Death \\
\hline & $\%$ & $\%$ & $\%$ & $\%$ & $\%$ \\
\hline $\begin{array}{l}\text { Gender } \\
\text { Females } \\
\text { Males }\end{array}$ & $\begin{array}{l}27.4^{\ddagger} \\
37.6\end{array}$ & $\begin{array}{l}21.3^{\ddagger} \\
29.3\end{array}$ & $\begin{array}{l}2.1^{\ddagger} \\
3.7\end{array}$ & $\begin{array}{l}2.0^{\ddagger} \\
3.5\end{array}$ & $\begin{array}{c}10.1^{\ddagger} \\
15.9\end{array}$ \\
\hline $\begin{array}{l}\text { Age (years) } \\
20-39 \\
40-59 \\
\geq 60\end{array}$ & $\begin{array}{l}13.5^{\ddagger} \\
34.4 \\
63.6\end{array}$ & $\begin{array}{l}11.0^{\ddagger} \\
26.7 \\
49.0\end{array}$ & $\begin{array}{l}0.8^{\ddagger} \\
3.1 \\
6.5\end{array}$ & $\begin{array}{l}1.0^{\ddagger} \\
2.9 \\
5.8\end{array}$ & $\begin{array}{l}2.4^{\ddagger} \\
12.0 \\
34.5\end{array}$ \\
\hline $\begin{array}{l}\text { Cardio-metaboli } \\
\text { None } \\
\text { One } \\
\text { Two or three }\end{array}$ & $\begin{array}{l}23.3^{\ddagger} \\
41.5 \\
57.3\end{array}$ & $\begin{array}{l}17.9^{\ddagger} \\
33.0 \\
44.5\end{array}$ & $\begin{array}{l}1.8^{\ddagger} \\
4.2 \\
5.8\end{array}$ & $\begin{array}{l}1.7^{\ddagger} \\
4.0 \\
5.4\end{array}$ & $\begin{array}{l}7.5^{\ddagger} \\
17.7 \\
28.8\end{array}$ \\
\hline $\begin{array}{l}\text { Other comorbidi } \\
\text { No } \\
\text { Yes }\end{array}$ & $\begin{array}{c}31.0^{\ddagger} \\
60.8\end{array}$ & $\begin{array}{c}24.2^{\ddagger} \\
45.8\end{array}$ & $\begin{array}{c}2.8^{\ddagger} \\
5.7\end{array}$ & $\begin{array}{l}2.7^{\ddagger} \\
5.3\end{array}$ & $\begin{array}{l}11.9^{\ddagger} \\
32.3\end{array}$ \\
\hline $\begin{array}{l}\text { Asthma } \\
\text { No } \\
\text { Yes }\end{array}$ & $\begin{array}{l}33.2^{\ddagger} \\
27.0\end{array}$ & $\begin{array}{c}25.9^{\dagger} \\
21.2\end{array}$ & $\begin{array}{l}3.0^{\circ} \\
2.0\end{array}$ & $\begin{array}{l}2.8 \\
4.1\end{array}$ & $\begin{array}{c}13.4^{\ddagger} \\
9.8\end{array}$ \\
\hline $\begin{array}{l}\text { Smoking } \\
\text { No } \\
\text { Yes }\end{array}$ & $\begin{array}{c}33.0^{+} \\
34.1\end{array}$ & $\begin{array}{l}25.6^{\ddagger} \\
27.8\end{array}$ & $\begin{array}{l}3.0 \\
3.2\end{array}$ & $\begin{array}{l}2.8 \\
2.8\end{array}$ & $\begin{array}{l}13.2^{\ddagger} \\
14.5\end{array}$ \\
\hline $\begin{array}{l}\text { Data source } \\
\text { Non-USMER } \\
\text { USMER }\end{array}$ & $\begin{array}{c}23.0^{\ddagger} \\
48.0\end{array}$ & $\begin{array}{l}17.9^{\ddagger} \\
37.4\end{array}$ & $\begin{array}{l}1.8^{\ddagger} \\
4.7\end{array}$ & $\begin{array}{l}2.1^{\ddagger} \\
4.0\end{array}$ & $\begin{array}{l}9.0^{\ddagger} \\
19.7\end{array}$ \\
\hline $\begin{array}{l}\text { Time-to-care } \\
\text { Tertile } 1 \\
\text { Tertile } 2 \\
\text { Tertile } 3\end{array}$ & $\begin{array}{l}33.6^{\ddagger} \\
28.0 \\
36.0\end{array}$ & $\begin{array}{l}22.6^{\ddagger} \\
23.5 \\
29.9\end{array}$ & $\begin{array}{l}2.0^{\ddagger} \\
3.0 \\
3.8\end{array}$ & $\begin{array}{l}1.9^{\ddagger} \\
2.6 \\
3.8\end{array}$ & $\begin{array}{l}13.7^{*} \\
11.3 \\
14.4\end{array}$ \\
\hline $\begin{array}{l}\text { Time of symptor } \\
\text { Tertile } 1 \\
\text { Tertile } 2 \\
\text { Tertile } 3\end{array}$ & $\begin{array}{l}36.6^{\ddagger} \\
43.2 \\
38.5\end{array}$ & $\begin{array}{l}19.9^{\ddagger} \\
24.3 \\
32.0\end{array}$ & $\begin{array}{l}1.5^{\ddagger} \\
2.4 \\
4.8\end{array}$ & $\begin{array}{l}1.6^{\ddagger} \\
2.3 \\
4.4\end{array}$ & $\begin{array}{l}7.5^{\ddagger} \\
12.7 \\
18.5\end{array}$ \\
\hline
\end{tabular}

severe forms of COVID-19 in the studied Mexican adults. A novel finding was that young adults in Mexico are at substantial risk of progressing to severe stages of infection when they have cardio-metabolic comorbidities, a risk that decreases as age advances. One possible explanation for this modifying effect of age is that there are differences between age cohorts with regard to weight gain and the metabolic changes it implies: considering that the obesity epidemic in Mexico began between the 1980s and the 1990s, older adults might have gained weight at older ages, while in young adults weight gain could have even occurred since childhood. In Norwegian adults, weight gain at between 25 and 50 years of age was observed to be associated with stroke; this risk was not present when weight gain occurred after 40 to 50 years of age. ${ }^{19}$ This may indicate that exposure to excess weight at an earlier age implies greater bodily alterations, which reduces the capacity to confront challenges such as COVID-19 infection. It is also possible that the drugs used in the treatment of comorbidities (the use of which may be more common in older people) act as protective factors against disease progression. ${ }^{11}$ 
Table 5. Poisson regression models where the dependent variables were the COVID progression indicators, and independent variables were demographic characteristics and medical history. Mexican adults with SARS-CoV-2 infection

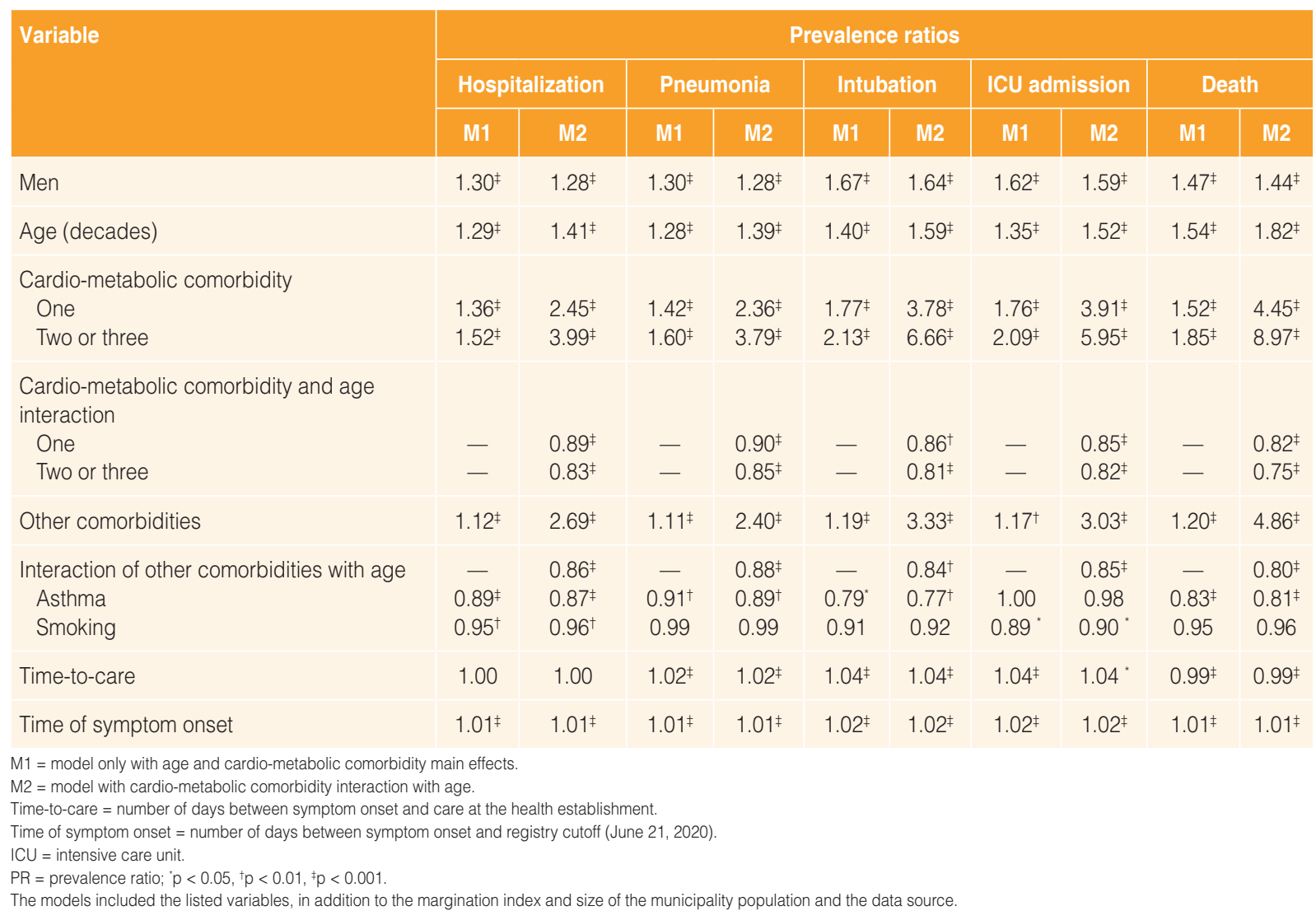

People with immune system disorders ${ }^{2,20,21}$ or with chronic kidney failure ${ }^{4,20}$ have been found to have a higher probability of COVID-19 progression; the same was consistently observed in the Mexican population with these comorbidities. Contrary to what might be expected, asthma and smoking were not associated in the Mexican population with an increased risk of the outcomes of interest, and were even associated with a lower probability of hospitalization in both cases and with death in the case of asthma. In other populations, smoking $6,10,20$ or respiratory disease ${ }^{2,20}$ have not been associated with COVID-19 progression either. Possibly, SARS-CoV-2 complications originate mainly at the cardiovascular and metabolic level. ${ }^{22}$ For this reason, previous compromise of the respiratory system might have a secondary role in disease progression.

Longer time to receive medical attention was positively related to pneumonia and ICU admission, but negatively to death. This suggests that the time elapsed without receiving medical attention since symptom onset directly influenced on the occurrence of complications of the disease. It is probable that those in whom receiving medical attention took longer required intensive care or intubation, which favored a reduction in the risk of death in those who had access to these resources. On the other hand, people who acquired the disease at the beginning of the epidemic had a higher risk of intubation, ICU admission and dying, a pattern that might be explained, in part, by the increase in knowledge about COVID-19 treatment among the health personnel, in addition to the fact that it has been promoted that people should attend medical services when they start having symptoms consistent with disease progression.

Unlike previous reports on hospital samples, the analysis herein presented was based on coronavirus infection confirmed cases in Mexico, which increases the possibility for the results to be extrapolated. It should also be recognized that there was a selection bias, since the Sana Distancia (Healthy Distance) National Campaign encouraged people with mild symptoms to stay home. To reduce the effect of this bias, the regression models included the time between 
Probability of hospitalization

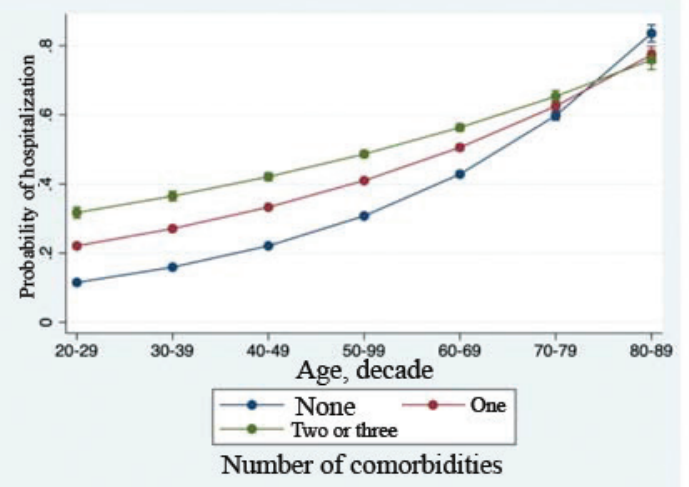

Probability of intubation
Probability of pneumonia

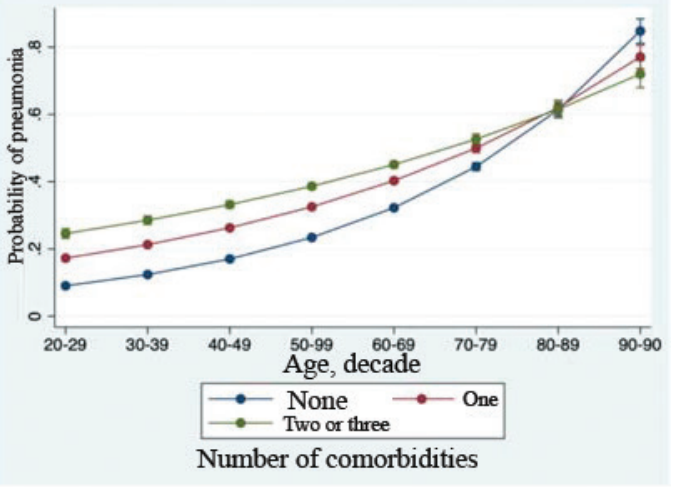

Probability of intensive care unit (ICU) admission
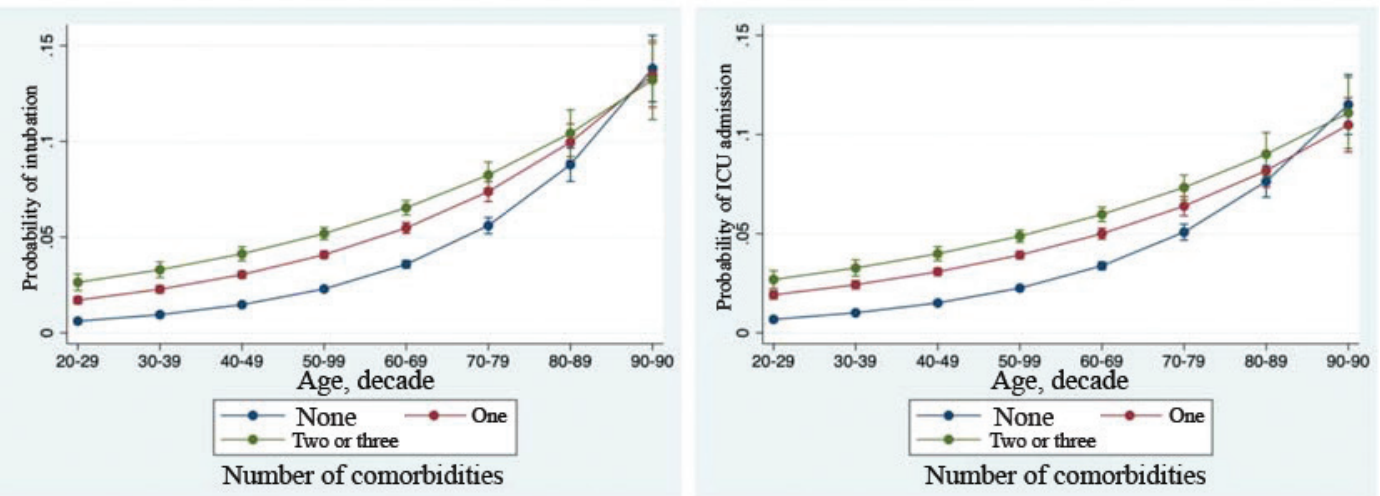

Probability of death

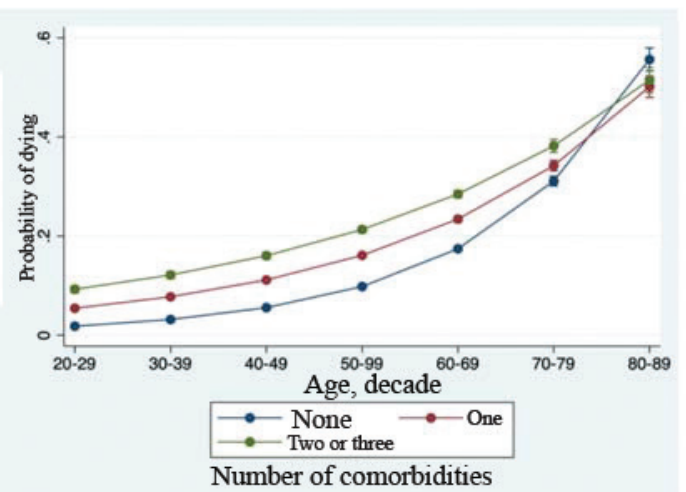

Figure 1. Adjusted probabilities of COVID-19-related severity outcomes, according to cardio-metabolic comorbidity and age in Mexican adults with SARS-CoV-2 infection. Adjusted probabilities based on the models reported in Table 5. Comorbidities include hypertension, obesity and diabetes.

symptom onset and the case registry cutoff date (June 21), thereby distinguishing whether the cases occurred at the beginning or at later stages of the epidemic.

In conclusion, cardio-metabolic diseases were the comorbidities that were more strongly associated with the development of COVID-19 complications, followed by heart disease, chronic kidney failure, immunosuppression and COPD. This result is worrying given the high rates of obesity, hypertension and diabetes existing in Mexico. Moreover, age acted as an effect-modifier of the relationship between the presence 
Probability of hospitalization

Probability of pneumonia
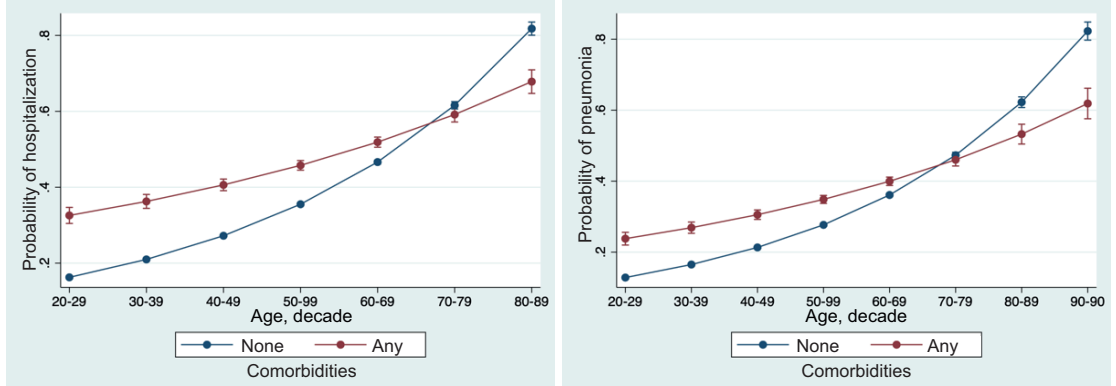

Probability of intubation

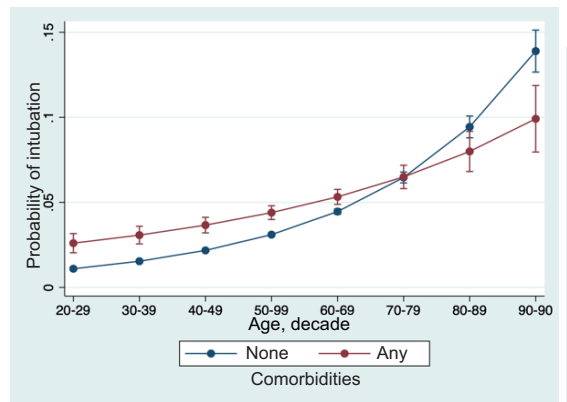

Probability of intensive care unit (ICU) admission

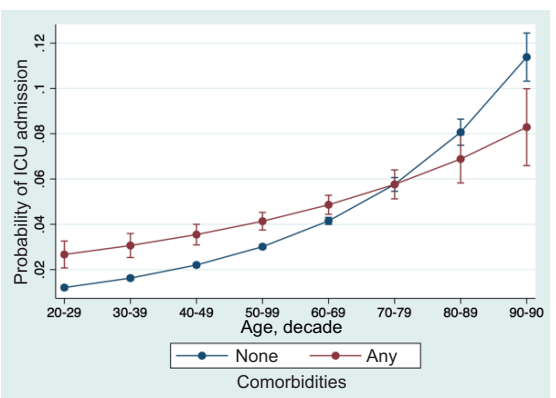

Probability of death

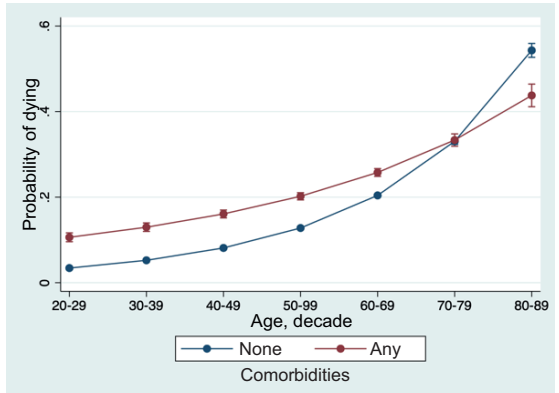

Figure 2. Adjusted probabilities of COVID-19-related severity outcomes according to other comorbidities and age in Mexican adults with SARSCoV-2 infection. Adjusted probabilities based on the models reported in Table 5. Comorbidities include immunosuppression, chronic kidney failure, heart disease and chronic obstructive pulmonary disease.

of cardio-metabolic comorbidities and indicators of disease severity. In contrast, smoking and asthma were not related to disease progression, which has been observed in other populations. It is important to rule out which factors or health conditions do not favor COVID-19 progression, since prevention efforts can focus on those groups that are really at risk, and generating unnecessary concern or psychological distress can be avoided in people who actually don't have such risk.

\section{Conflict of interests}

The authors declare that they have no conflicts of interest related to the manuscript.

\section{Funding}

The authors did not receive any subsidy for carrying out the manuscript.

\section{Ethical disclosures}

Protection of human and animal subjects The authors declare that no experiments were performed on humans or animals for this research.

Confidentiality of data The authors declare that they have followed the protocols of their work center on the publication of patient data.

Right to privacy and informed consent The authors obtained informed consent from the patients or 
subjects referred to in the article. This document is in the possession of the corresponding author.

\section{References}

1. Li B, Yang J, Zhao F, Zhi L, Wang X, Liu L, et al. Prevalence and impact of cardiovascular metabolic diseases on COVID-19 in China. Clin Res Cardiol. 2020;109:531-538.

2. Myers L, Parodi S, Escobar G, Liu V. Characteristics of hospitalized adults with COVID-19 in an integrated health care system in California. JAMA. 2020;323:2195-2198.

3. Huang C, Wang Y, Li X, Ren L, Zhao J, Hu Y, et al. Clinical features of patients infected with 2019 novel coronavirus in Wuhan, China. Lancet. 2020;395:497-506.

4. Guan WJ, Ni ZY, Hu Y, Liang WH, Ou CQ, He JX, et al. Clinical characteristics of coronavirus disease 2019 in China. N Engl J Med. 2020;382:1708-1720.

5. Zhou F, Yu T, Du R, Fan G, Liu Y, Liu Z, et al. Clinical course and risk factors for mortality of adult inpatients with COVID-19 in Wuhan, China: a retrospective cohort study. Lancet. 2020;395:1054-1062.

6. Lippi G, Henry BM. Active smoking is not associated with severity of coronavirus disease 2019 (COVID-19). Eur J Intern Med. 2020;75:107-108.

7. Guo FR. Active smoking is associated with severity of coronavirus disease 2019 (COVID-19): an update of a meta-analysis. Tob Induc Dis. 2020;18:37.

8. Vardavas $\mathrm{CI}$, Nikitara K. COVID-19 and smoking: a systematic review of the evidence. Tob Induc Dis. 2020;18:20.

9. Berlin I, Thomas D, Le Faou AL, Cornuz J. COVID-19 and smoking. Nicotine Tob Res. 2020:ntaa059.

10. Rossato M, Russo L, Mazzocut S, Di Vincenzo A, Fioretto P, Vettor R. Current smoking is not associated with COVID-19. Eur Respir J. 2020;55:2001290.

11. Singh A, Gupta R, Misra A. Comorbidities in COVID-19: outcomes in hypertensive cohort and controversies with renin angiotensin system blockers. Diabetes Metab Syndr. 2020;14:283-287.
12. Barquera S, Campos-Nonato I, Hernández-Barrera L, Pedroza-Tobías A, Rivera-Dommarco J. Prevalencia de obesidad en adultos mexicanos, ENSANUT 2012. Salud Publica Mex. 2013;55.

13. Campos-Nonato I, Cuevas L, González D, Hernández-Barrera L, Shamah T, Gonzáles T, et al. Epidemiología de la obesidad y sus principales comorbilidades en México. In: Rivera-Dommarco JA, Colchero MA, Fuentes ML, González-de Cosío T, Aguilar Salinas CA, Hernández G, et al. (editors). La obesidad en México. Estado de la política pública y recomendaciones para su prevención y control. Mexico: Instituto Nacional de Salud Pública; 2018.

14. Secretaría de Salud [Internet]. Mexico: Datos abiertos-bases históricas; 2020.

15. Secretaría de Salud [Internet]. Mexico: Aviso epidemiológico. Enfermedad COVID-19 por SARS-CoV-2; 2020.

16. Consejo Nacional de Población [Internet]. Mexico: Datos abiertos del índice de marginación; 2016.

17. Simonnet A, Chetboun M, Poissy J, Raverdy V, Noulette J, Duhamel A et al. High prevalence of obesity in severe acute respiratory syndrome coronavirus-2 (SARS-CoV-2) requiring invasive mechanical ventilation. Obesity (Silver Spring). 2020;28:1195-1199.

18. Lighter J, Phillips M, Hochman S, Sterling S, Johnson D, Francois F, et al. Obesity in patients younger than 60 years is a risk factor for $\mathrm{CO}$ VID-19 hospital admission. Clin Infect Dis. 2020;71:896-897.

19. Prestgaard E, Mariampillai J, Engeseth K, Erikssen J, Bodegard J, Liestol $\mathrm{K}$, et al. Change in body weight and long-term risk of stroke and death in healthy men. Stroke. 2020;51:1435-1441.

20. Petrilli C, Jones S, Yang J, Rajagopalan H, O'Donnell L, Chernyak Y, et al. Factors associated with hospitalization and critical illness among 4,103 patients with Covid-19 disease in New York City. medRxiv. 2020.

21. Richardson S, Hirsch J, Narasimhan M, Crawford J, McGinn T, Davidson K, et al. Presenting characteristics, comorbidities, and outcomes among 5700 patients hospitalized with COVID-19 in the New York City area. JAMA. 2020;323:2052-2059.

22. Oxley TJ, Mock J, Majidi S, Kellner CP, Shoirah H, Singh IP, et al. Large-vessel stroke as a presenting feature of Covid-19 in the young. $\mathrm{N}$ Engl J Med. 2020;382:e60 